\title{
Mali: a new challenge for peacekeeping
}

\author{
RITTER Noémi ${ }^{1}$
}

\begin{abstract}
In the past few years many conflicts have intensified in Africa, one of which have caused a new peacekeeping mission to be deployed to Mali, and already existing operations to be strengthened. Mali was the first victim of the chaos caused by the Arab Spring and the international intervention in Libya. The heavily armed Tuareg returned to Mali after the Libyan intervention, and their separatist aspirations caused an interior conflict that escalated when terrorist groups got involved. A democratically functioning country collapsed from one day to another. The crisis in Mali is a difficult challenge for the international community because it has to organize a multidimensional peacekeeping mission, while having to fight against terrorism. Moreover, the global economic crisis forced these nations to reduce their military spending without compromising effectiveness. The present paper deals with the complexity of the conflict in Mali and examines whether the United Nations Multidimensional Integrated Stabilization Mission in Mali (MINUSMA), the peacekeeping mission in Mali, is able to comply with the expected requirements.
\end{abstract}

Keywords: Mali, terrorism, international intervention, peacekeeping mission, cooperation

\section{Introduction}

The international community has a long history in peacekeeping. In the past 20 years peacekeeping missions have rapidly developed. The African Continent had a leading role in this development. [1] After the Cold War many countries in Africa sequentially collapsed. The financial assistance from the super powers dried up, economic problems came to the surface in addition to other historical conflicts that led sometimes to bloody clashes or even worse events. Then international peacekeeping operations with limited mandates were deployed into the countries most affected by the conflicts. Mostly these missions were unsuccessful in peacekeeping. The massacre in Rwanda made the international community reconsider the framework and possibilities of peacekeeping. [2]

The past few years saw similar crises triggered by revolutions in the Middle-East, which then spread to Africa. The conflicts in the African countries have some common features rooted in their historical background but every conflict has its own specific character. In this article I try to examine the new challenges of peacekeeping in Africa through the crisis in Mali. The short history of Mali could explain the roots of the conflict not just in Mali but in Africa. Economic and ethnic conflicts are common in the African countries. The global economic crises and the aftermaths of the revolutions in the Arabic world created new challenges for states in the African region and changed the security environment in the region. [3] Mali

1 ritter.noemi@hotmail.com 
was one of the most democratic countries in Africa but it collapsed in a short time as Mali's interior crises increased into an international problem when the radical Islamists infiltrated the country. The escalation in Mali was the first sign of the vulnerability of African states and of the fragility of international peace.

MINUSMA was the latest peacekeeping mission deployed in Mali after an international intervention but when it started its operation Mali was too far from peace. The new trends in the African conflicts resulted in some changes in the peacekeeping missions.

\section{An introduction to Mali}

The Republic of Mali is located in West Africa. It is bordered by Algeria, Niger, Burkina Faso, Cote d'Ivoire, Guinea, Senegal and Mauritania. Its territory is 1240192 square kilometers, making it the $24^{\text {th }}$ largest country on Earth and the $8^{\text {th }}$ in Africa. Its capital city is Bamako. Mali is a landlocked country with two rivers: the Niger and the Senegal. The climate is subtropical in the south and arid in the north. Mali is mostly flat and the northern area lies in the Sahara Desert. Its highest point is Hombori Tondo. Mali's population is slightly below 16 million and is ethnically divided: $50 \%$ of the population is Mande, $17 \%$ Peul, $12 \%$ Voltaic, $10 \%$ Tuareg and Moor, 6\% Songhai. The official language is French. More than $94 \%$ of the people are Muslim. The majority of the inhabitants live in the southern regions of the country near the rivers. [4]

Mali's northern and southern parts are so different in many aspects that it has caused conflicts through its history. Northern Mali is covered by sand and neither the land nor the climate is suitable for agriculture. The northern population is characterized by ethnic and cultural diversity, there are sedentary and nomadic groups living together. The main minority in the northern area is Tuareg, traditionally connected to North Africa with their Berber Arab origin, while the majority of Malian people are Black African with African traditions. [5]

Mali is the $25^{\text {th }}$ poorest country in the World, agriculture, cotton and a gold mining sector have the main role in its economy and the country has some uranium deposits too. [4] In the past few years the region suffered from droughts that increased its economic problems.

Mali was a French colony in the $19^{\text {th }}$ century as part of French Sudan. In 1959 Senegal and Mali got its autonomy as the part of the French Community and they formed the Mali Federation. One year later both countries became independent.

The first president of Mali was Modibo Keita, who stabilized his own power in a dictatorship and built a single-party system. In 1968, just like in Egypt and Libya, there was a military coup d'état against Keita, whom had returned to the Franc Zone due to economic reasons. After a bloodless revolution Lieutenant Moussa Traoré seized power but the democratic transition was not completed until 1992. Traoré declared a new constitution in 1974 and at the same time he established a political party, called the Democratic Union of the Malian People. Mali held its first election in 1979. Traoré won it and consolidated his single-party regime in the framework of civil legislation. In the 1980s students organized an uprising against the anti-democratic regime. The riot did not reach its aims but did mark the beginning of those changes which led to a real democratic transition in 1992. Traoré recognized that the system needed liberalization in the economy and allowed independent press and political association. These reforms established the background of a democratic change. In 1991 students led a riot again, with the support of military officers. Traoré was arrested. Mali became 
a democratic country with a semi-presidential multiparty system. Alpha Oumar Konoré was the first democratically elected president of Mali for two terms, then in 2002 Amadou Toumani Touré, who had been the leader of the military group in the 1991 revolution, won the election. Touré was the president until March 2012 when a military coup removed him from power and a transitional government, led by Dioncounda Traoré, was established. [6]

\section{The background of the crisis in Mali}

Mali was the most democratic country in Africa in the past 20 years. Although Mali was the first victim of the North African unrest, there are many other fragile states in its neighbourhood. There were three main reasons for the crises in Mali. Firstly, there was a historical conflict in society. The Tuareg minority, who lives in the northern part of the country, wanted autonomy in the Azawad region. Moreover, Mali had to face deeper economic problems worsened by drought and increased by the global economic crisis. Slavery further escalated the social and political conflicts. Secondly, there was a revolutionary wave in the Arabic countries, which started in North Africa. Finally, radical Islamist groups joined the rebels thus the Mali crisis presented a threat to the regional and the international security.

We shall try to describe the connection of these three main reasons and explain how they escalate a crisis which necessitated an international intervention in the end. As we mentioned above, Mali is ethnically divided. Tuareg are nomadic Berber people wandering in the desert of the Sahara. ${ }^{2}$ They live in northern Mali, Niger, Algeria, and Mauritania. After the French colonization the western powers established borders without regard for the ethnic groups. The newly drawn borders are the reason for many conflicts all over Africa because they fragmented the tribes and ethnic groups. When Mali gained independence in 1960 Tuareg wanted autonomy but the government forces were better equipped so they repressed the Tuareg rebellion then they established strong military control over the three northern regions. Socialism and nationalism effected Keitha's governing method and he took the land from the Tuareg, so they fled to the neighbouring countries: Algeria, Niger, Mauritania and Libya. While Mali went on to a democratic transition in 1992 the Tuareg started an insurgency again. The transitional government was ready for negotiations with two Tuareg factions: the Azawad Popular Movement and the Arabic Islamic Front of Azawad, but not all the Tuareg community got involved. [7] At the end of this process the National Pact was signed. The Tuareg people got political rights, the government granted their local representation and their combatants were allowed to join the Malian Armed Forces. These agreements were not able to put an end to the violence as the Islamic Front of Azawad did not sign the National Pact and continued the attacks.

The final moment which led to the Malian crisis was the Libyan regime change. After Gaddafi's return in Africa in the 1970s he welcomed the Tuareg migrants. Gaddafi integrated them into the Libyan Forces. They played an active role in the civil war on both sides. After Gaddafi's death these experienced and heavily armed fighters had to leave Libya. They returned into Mali and that triggered the Mali crisis.

2 Tuareg: In the past Tuareg people connected East and West Africa, they had the main role in the transSaharan-trade. 


\section{The main actors of the conflict}

This conflict was more complicated than it seemed. The rebel Tuareg groups were fragmented, with different objectives and the turmoil in Mali attracted terrorist groups that established their bases in the country.

In October 2011 Tuareg fighters founded an organization called National Movement of Liberation of Azawad (MNLA, in French: Mouvement National pour la Libération de l'Azawad). This was the moderate wing of the rebellion because it was a nationalist movement not an Islamist formation. Their aim was to establish an independent and secular country in the territory of Azawad. During the escalation the MNLA became fragmented and some smaller groups broke off.

Ansar al-Dine is another group founded by a Touareg fighter Iyad Ag Ghali. This group is an Islamist group but it is not part of an international terrorist network. Ansar al-Dine aims at creating an Islamic country in Mali, to be governed by Sharia law. At the beginning of the conflict the MNLA and Ansar al-Dine co-operated, but after Northern Mali fell Ansar al-Dine took control from the MNLA and started to reach its own goals. [8]

Al-Qaida in the Islamic Maghreb (AQIM) is a regional jihadist group in the Sahel, a branch of al-Qaida. It is not clear if Ansar al-Dine and AQIM are connected to each other but both have similar objectives. Their members were not only Malian or Tuareg but there were well trained fighters who had come from Afghanistan and Somalia, and young people from the neighbouring countries. [9] The movement of Unity and Jihad in West Africa (MUJWA) is another terrorist organization which split off from AQIM. Their goal is the same but MUJWA operates in West Africa and its leaders are black African. [10] This group was formed in Mauritania in mid-2011. The objectives of the MNLA and Ansar al-Dine do not meet: the MNLA wants autonomy for the Tuareg while Ansar al-Dine envisions an Islamic Mali. The real danger for regional stability is AQIM and MUJWA. [8]

\section{The escalation of the conflict and the international military intervention}

The Tuareg rebellion started in January 2012. In response, government troops were deployed but the Malian Forces were not able to isolate the riot in the north. While the Tuareg aspiration for autonomy were rising the government of Mali had to face internal political problems. The MNLA leaders stated that the autonomy of Azawad is off the negotiation agenda and they started the occupation of the northern cities. On $22^{\text {nd }}$ March in 2012 a group of Malian officers overthrew the civilian government having seen its inability in managing the northern conflict. The leader of the coup d'état, officer Amadou Sanogo, was trained by the US military while fighting against terrorism. ${ }^{3}$ [11]

By the end of March the MNLA had taken control over Kidal, Gao and Timbuktu: the main cities in the northern part of the country. At the beginning of the insurgency the MNLA and Ansar al-Dine fought together with the Malian army, until they occupied the whole northern region. On $6^{\text {th }}$ April the MNLA declared the separation of the North as an inde-

3 US AFRICOM was founded in 2008 as part of counter terrorism in cooperation with the countries in the region. In this frame US troops were deployed and organized training for the national armed forces. 
pendent state: Azawad. After the separation the Islamists seized power from the MNLA, implemented Sharia laws and by the autumn of 2012 most cities were in Islamist hands. As the northern conflict widened there was a fear that it could further extend in the southern part of the country and spread in the region. The government of Mali and Economic Community of West African States (ECOWAS) requested an international military intervention. On $12^{\text {th }}$ October 2012 the United Nations Security Council passed Resolution 2071, which was an action plan for military intervention in Mali. According to this plan ECOWAS and the African Union were to lead the forces which had a limited timeframe of 45 days. [6] This resolution did not authorize the deployment of the international forces. One month later the United Nations Security Council adopted Resolution 2085, which gave a mandate for the intervention of African-led troops and the French forces to take all the necessary measures. [12]

\section{Operation Serval}

France supported the intervention from the beginning of the crisis not only because of the historical background but also for political reasons: the uranium from neighbouring Niger ensures a large part of the French energy supply and the escalation of the conflict could threaten its access. [13] The French forces started their operation on $11^{\text {th }}$ January 2013. The intervention was urgent because the radical groups captured the city of Konna, with a military airport nearby which had real importance in logistical terms for foreign troops. [14] At the beginning of the operation France did not deploy land forces except the Special Forces and as in Libya they attacked the Islamist targets with air strikes launched from armed Gazelle helicopters, Mirage and Rafale fighter jets. The French operations quickly suppressed the Islamist militias. The African-led mission had been deployed sooner than planned with the first troops arriving on $17^{\text {th }}$ January. Due to international actions in Mali the Algerian wing of AQIM attacked a gas field in Algeria and took the foreigner workers hostage. The Algerian Security Forces acted quickly but seven hostages became victims of this incident. [15]

France continued its operation assisting the Malian army. By the end of January the main cities in the north were cleared of the Islamist forces but it did not mean the end of the crisis. The Islamist groups retreated into the Adrar des Ifoghas Mountains and continued their attacks. French forces were planned to be withdrawn in the end of March 2013, but the situation in Mali forced them to stay longer as the Malian army would have been too weak to fight with the Islamist units alone. The Chadian troops played an important role in resolving the conflict in Mali. When the French forces pushed back the Islamist groups in the Arder des Ifoghas and Tighargar the experienced Chadian troops followed them and destroyed their bases and killed the terrorist leaders. [16] Until then the terrorist groups presented a real threat to Mali, they made their presence felt by constant terrorist attacks. France started the withdrawal of half of its troops but approximately 1000 French troops stayed in Mali in cooperation with the international peacekeeping mission. [17]

\section{African-led International Support Mission in Mali (AFISMA)}

The French forces did not fight alone with the Islamists in the military intervention; well organized and coordinated cooperation with the troops of AFISMA was witnessed. As I have mentioned above, the African-led International Support Mission was established by 
the United Nations Security Council Resolution with a one-year mandate to restore peace and security in Mali. The European Union created a support mission beside the French and African troops. It was a training mission for developing the Malian Armed Forces. ${ }^{4}$ [18] The French intervention and the forces of AFISMA worked in cooperation, but their motivation to intervene was far different. France wanted to defend its political interests in the region while AFISMA came to put an end to the humanitarian crisis in Mali and prevent the escalation of the conflict in the region. Despite the French participation the mission of AFISMA did not alter the well-tried method in peacekeeping with the western countries and international organizations providing the financial background and the equipment for the military operations while $3^{\text {rd }}$ world countries deployed their soldiers. [19] The main financial contributors to AFISMA were: Japan with 120 million USD, the United States 96 million USD and the EU 75 million USD. [20] The member states of the African Union and ECOWAST sent the troops for AFISMA. ${ }^{5}$ [20] The initial plan was to deploy 3000 troops in Mali but when the operations started their strength increased to over 6000. Chadian, Nigerian and ECOWAS troops were over-represented in the forces of AFISMA.

As the objectives of the peacekeeping missions were to achieve a longstanding solution, AFISMA had to act in wider dimensions of security during the military actions and further on. [21] AFISMA took part in political solutions, ECOWAS mentored the process of negotiations between the transitional government and MNLA leaders. As a result of the mediation they signed a peace deal on $18^{\text {th }}$ June 2013. [22] Experiencing the incapacity of the Malian security forces the mission had to assist with rebuilding the army of Mali. AFISMA took part in legal reforms with a special regard for minority rights. After the intervention reached its main goal to stop the extremists and stabilize the northern region AFISMA transformed into a multidimensional peace-building mission supporting the stabilization of peace and security.

\section{MINUSMA}

In the end of February 2012 the transitional government took back control in the northern cities, as a result of the international intervention, and started peace talks with the MNLA. ${ }^{6}$ [23] Thanks to these successful military actions the Islamist groups were displaced from their bases in the mountains. It seemed that the crisis in Mali subsided but it did not mean the end of the conflict. The extremists did not give up their aims and their countless attacks remained, marking their presence. The Malian government was urged to take steps in the transition with the assistance of MINUSMA, European Union Training Mission (EUTM) Mali and the French troops. [24]

On $25^{\text {th }}$ April 2013 the United Nations Security Council passed resolution 2100. AFISMA was transformed into a peacekeeping mission called Multidimensional Integrated Stabilization Mission in Mali. On $1^{\text {st }}$ July 2013 MINUSMA took the authority from AFISMA. MINUSMA started its operation with 12640 uniformed personnel and civil staff. The mandate of this mission is wide enough. Although the northern territory came under the control of the Malian government the country was far from stability yet. MINUSMA got a large mandate

4 Hungary also participated in the mission of EUTM Mali

5 The African countries that contributed to AFISMA with troops: Nigeria, Ghana, Chad, Niger, Benin, Burundi, Senegal, Cote d'Ivoire, Liberia, Togo, Burkina Faso, and Sierra Leone.

618 June 2013 MNLA and the government of Mali signed a peace deal in Burkina Faso 
regarding the complexity of the situation in Mali. The mission was established as a peacekeeping mission but it has some specifications, namely: its mandate did not authorize the use of force just the limited use of weapons for self-defence and protecting civilians, which means they can take military action at tactical level only. MINUSMA stands on the line of a traditional peacekeeping mission and peace-enforcement. [25] The most important aim of this mission is to guarantee the peace and the security in Mali. To achieve this goal the government troops have to stabilize the key centers while they are assisting with rebuilding the security sector. The re-establishment of state authority in the country had to be provided support. This mission was called to promote the reconciliation process, support the national dialogue and take part in the implementation of the transition in Mali. The mission had elements to develop human rights and programs for disarmament and reintegration. [26]

Until now the mission has achieved little success but there have been small steps made, such as elections held in the summer, which could be the first step to rebuilding the political body of the country. There was a backward step too when the MNLA ended the ceasefire after the security forces had clashed with protesters. MINUSMA peacekeepers have to face many challenges and that makes the solution more difficult. On the one hand there are the interior problems in the country like the diversity of ethnicities and the deep economic problems. On the other hand there is regional instability with increasing extremism. Having regarded the circumstances I do not think MINUSMA will succeed in its mission in the near future. The success of the MINUSMA mission is largely inhibited by the strengthening terrorist groups in the region. Some participant African states, like Nigeria, were forced to recall their troops from the peacekeeping mission due to the radical escalation of the interior conflict.

\section{Conclusion}

The Northern-Mali crisis started as an interior conflict based on three main problems: the ethnic diversity in society, the cultural differences between the eastern and northern parts of the country and economic reasons. [6]

Due to external factors the interior problems escalated and this turnaround endangered international peace and security. The aftermath of the Arab spring and the international intervention in Libya exacerbated the existing ethnic conflict when armed Tuareg returned from Libya complemented with terrorist elements. A military coup d'état overthrew the government when the separatist Tuareg rebels captured cities in the north and the Islamist groups took control from the Tuareg fighters. The transitional government of Mali requested international intervention. This request and the spread of terrorism gave the mandate to the international community to intervene. The regional instability and the collapsed security sector of Mali predicted the necessity of a peacekeeping operation after international intervention. The French forces and the troops of AFISMA in cooperation with the security forces of Mali had taken rapid military actions, recaptured the main cities in the north and driven out the Islamist groups.

After the intervention AFISMA was transformed into a peacekeeping mission. MINUSMA functioned as the new generation of peacekeeping. It was authorized to complete multidimensional operations in security, political, economic, social and cultural dimensions. This mission works in close cooperation with the French troops as regards the fragile security in the country. The French forces continued their military actions against the Islamists. MINUS- 
MA have to face a complex conflict in Mali and asymmetric challenges. The mission has not succeeded yet. The unrest is escalating in the region and the terrorist elements are gaining strength. That and the fact that some participating countries had to withdraw their troops because of their own security, threatened by the terrorist rebels, hampered the effectiveness of the mission. There are old conflicts intensifying in South-Sudan, the Democratic Republic in Congo and the Central African Republic. The international community has to divide its troops and financial resources. At present it seems that the stabilization of Mali will be a longer process.

\section{References}

[1] BESENYŐ J.: Magyar békefenntartók Afrikában. Budapest: Katonai Nemzetbiztonsági Szolgálat Tudományos Tanácsa, 2013.

[2] BESENYŐ J.: Az Afrikai konfliktusok és kezelésük sajátosságai, a békefenntartó múveletek során szerzett tapasztalatok. Felderítő Szemle, VII 3 (2008) 5-15.

[3] BESENYŐ J.: Arab tavasz — politikai rendszerváltás az észak-afrikai arab államokban. Kül-Világ, VIII. 4 (2011), 51-75. http://www.kul-vilag.hu/2011/04/besenyo.pdf (downloaded: 0701 2014)

[4] CIA: CIA World Factbook, Mali. https://www.cia.gov/library/publications/the-worldfactbook/geos/ml.html (downloaded: 2712 2013)

[5] BESENYŐ J., MILETICS P.: Mali országismertető. Budapest: MH Geoinformációs Szolgálat, 2013. http://www.kalasnyikov.hu/dokumentumok/orszagismerteto_mali.pdf (downloaded: 0701 2014)

[6] BESENYŐ J.: Háború Európa előterében: a Mali krízis. Sereg Szemle, XI 1 (2013) 105-134. http://www.scribd.com/doc/161012825/Haboru-Europa-el\%C5\%91tereben-a-Mali-krizis (downloaded: 0101 2014)

[7] DEVON, D. B.: The Crisis in Mali: A Historical Perspective on the Tuareg People. Global Research, 2013. http://www.globalresearch.ca/the-crisis-in-mali-a-historical-perspective-onthe-tuareg-people/5321407 (downloaded: 2712 2013)

[8] THURSTON, A., LEBOVIZT, A.: A Handbook on Mali's 2012-2013 crisis. Institute for the Study of Islamic Thought in Africa, Working Paper No. 13-001.m2013. http://www. bcics.northwestern.edu/documents/workingpapers/ISITA-13-001-Thurston-Lebovich.pdf (downloaded: 2712 2013)

[9] BBC: Mali crisis: Key players. BBC News, 1203 2013. http://www.bbc.co.uk/news/worldafrica-17582909 (downloaded: 2712 2013); GUICHAOAU, Y.: The genesis of terrorism in the Sahara: Al-Qaida in the Islamic Maghreb. Open Security, 2403 211. http://www. opendemocracy.net/opensecurity/yvan-guichaoua/genesis-of-terrorism-in-sahara-al-qaedain-islamic-maghreb (downloaded: 2712 2013)

[10] WELSH, M. Y.: Making sense of Mali’s armed groups. Aljazeera, 1701 2013. http://www. aljazeera.com/indepth/features/2013/01/20131139522812326.html (downloaded: 2912 2013)

[11] HALLINAN, C. M.: The Crisis in Mali. International Policy Digest, 2608 2012. http:// www.internationalpolicydigest.org/2012/08/26/the-crisis-in-mali/ (downloaded: 2812 2013)

[12] UN SECURITY COUNCIL: Adopting Resolution 2071 (2012), Security Council Demands That Armed Groups, Cease Human Rights Abuses, Humanitarian Violations in Northern Mali. Security Council 6846th Meeting (PM), New York, 1210 2012. http://www.un.org/ News/Press/docs/2012/sc10789.doc.htm (downloaded: 2812 2013); UN SECURITY COUNCIL: Security Council Authorizes Deployment of African-led International Support Mission in Mali for Initial Year-Long Period (Resolution 2085). Security Council 6846th Meeting (PM), New York, 2012 2012. http://www.un.org/News/Press/docs/2012/sc10870. doc.htm (downloaded: 2812 2013) 
[13] EILSTRUP-SANGIOVANNI, M.: The EU's Common Security and Defense Policy and the Mali Crisis. E-International Relations, 1608 2013. http://www.e-ir.info/2013/08/16/the-euscommon-security-and-defense-policy-and-the-mali-crisis/ (downloaded: 2612 2013)

[14] AFP: Mali Crisis: Timeline. The Telegraph, 1501 2013. http://www.telegraph.co.uk/news/ worldnews/africaandindianocean/mali/9801760/Mali-crisis-timeline.html (downloaded: 28 12 2013)

[15] BBC: Algeria hostage crisis: What we know. BBC News, 2101 2013. http://www.bbc.co.uk/ news/world-africa-21087732 (downloaded: 2812 2013)

[16] BBC: Islamist militant Mokhtar Belmokhtar "killed in Mali”. BBC News, 0303 2013. http:// www.bbc.co.uk/news/world-africa-21645769 (downloaded: 2812 2013)

[17] EUTM MALI official webpage, http://www.eutmmali.eu/ (downloaded: 2712 2013); INTERNATIONAL RELATIONS AND SECURITY NETWORK: Mali's Challenges PostFrench Intervention. Zurich, 0309 2013. http://www.isn.ethz.ch/Digital-Library/Articles/ Detail/?id=168531\&lng=en (downloaded: 2712 2013)

[18] BESENYŐ J.: Az Európai Unió kiképző művelete Maliban és a magyar szerepvállalás. Honvédségi Szemle, 20135 68-76. http://www.honvedelem.hu/container/files/ attachments/40386/hsz_2013_5.pdf (downloaded: 2812 2013)

[19] BESENYŐ J.: The European Union mission in Mali — Hungary's involvement in the mission, Contemporary Military Challenges. Sodobni Vojaski Izzivi, 201311 25-37. http://www.slovenskavojska.si/fileadmin/slovenska_vojska/pdf/vojaski_izzivi/svi_15_3.pdf (downloaded: 2812 2013); VORRATH, J.: Imbalances in the African Peace and Security Architecture. SWP Comment. 09 2012, 1-4. http://www.swp-berlin.org/fileadmin/contents/ products/comments/2012C29_vrr.pdf (downloaded: 2812 2013)

[20] MARU, M. T.: AFISMA: Military ahead of Politics. Aljazeera Center for Studies, 1802 2013. http://studies.aljazeera.net/en/reports/2013/02/20132148940690455.htm (downloaded: 2812 2013)

[21] MINUSMA official homepage. http://www.un.org/en/peacekeeping/missions/minusma/ (downloaded: 2812 2013)

[22] BBC: Mali and Tuareg rebels sign peace deal. BBC News, 1806 2013. http://www.bbc. co.uk/news/world-africa-22961519 (downloaded: 2912 2013)

[23] Malian indirect peace talks start with Tuareg in Burkina Faso. Africa - News and Analysis, 1106 2013. http://africajournalismtheworld.com/2013/06/11/malian-indirect-peace-talksstart-with-tuareg-in-burkina-faso/ (downloaded: 2912 2013)

[24] INTERNATIONAL CRISIS GROUP: Mali: Security, Dialogue and Meaningful Reform. Africa Report No. 201, Brussels: ICG Headquarters, 1104 2013. http://www.crisisgroup. org/ /media/Files/africa/west-africa/mali/201-mali-securiser-dialoguer-et-reformer-enprofondeur-english.pdf (downloaded: 2812 2013)

[25] TARDY, T.: Mali: the UN takes over. Issue Alert, 10 (2013) 1-2. http://www.iss.europa.eu/ uploads/media/Alert_Mali.pdf (downloaded: 2912 2013)

[26] BERGAMASCHI, I.: MINUSMA: Initial steps, achievements, and challenges. NOREF Policy Brief, 09 2013. 1-4. http://www.peacebuilding.no/var/ezflow_site/storage/original/ application/89da563832be4b62d09bc99edc0cf080.pdf (downloaded: 2912 2013) 